\title{
CHPS (Congenital Hypertrophic Pyloric Stenosis)
}

\section{Ajit Sahay*}

Department of Pediatrics, Consultant Pediatrician, Santevita Hospital Ranchi, Rani Hospital Ranchi, India

*Corresponding Author: Ajit Sahay, Department of Pediatrics, Consultant Pediatrician, Santevita Hospital Ranchi, Rani Hospital Ranchi, India.
Received: March 30, 2021

Published: April 16, 2021

(C) All rights are reserved by Ajit Sahay.

\section{Overview}

One 34 weeker male child born by IVF aged 29 Days presented in my OPD at Santevita Hospital on 29 Nov 2020 with complaints of crying and repeated vomits for past 1 day and similar history previously as well. Suspecting Urinary Tract Infection and in back of mind CHPS, I ordered

- Urine routine examination and USG abdomen.

- $\quad$ Surprisingly both were reported normal.

So, I assumed as a case of aerophagy and kept the child in observation in OPD basis. The same day evening the child had repeated vomiting and was admitted at Rani Hospital. A repeat USG was done and CHPS was confirmed.

The Pediatric Surgeon was informed and surgery was planned for next day morning. But on the request of the parents the child was airlifted by Air Ambulance to SGRH New Delhi and was examined by Dr Satish Kumar Aggarwal and again USG and other relevant investigations were done.

Finally, CHPS was confirmed and corrective surgery was done successfully.

Now the child is back home to Ranchi and is thriving well.

How we can miss a diagnosis, in a neonate.

Here in my case The Radiologist probably couldn't pick the exact pathology in the USG done initially. The same child while being admitted after 12 to 14 hours in The Tertiary Care Children Hospital (Rani Hospital RANCHI) the Radiologist instantly picked up the pathology and was diagnosed as CHPS and Pediatric Surgeon also had the same view.

\section{Conclusion}

We should apply our Clinical Teachings First and accordingly in cases of doubt even in a Normal Reported Test (As in this case) we should not hesitate to repeat the same test at some other centre with expertise.

\section{Acknowledgements}

Dr Bala MD (Consultant Radiologist Rani Hospital Ranchi).

Dr Rajesh MD DM (Neonatalogy) Rani Hospital Ranchi.

Dr Ramanuj Kumar MS MCh (Pediatric Surgery) Rani Hospital Ranchi.

Dr Satish Kumar Aggarwal Pediatric Surgeon (Sir Ganga Ram Hospital New Delhi).

\section{Assets from publication with us}

- Prompt Acknowledgement after receiving the article

- Thorough Double blinded peer review

- Rapid Publication

- Issue of Publication Certificate

- High visibility of your Published work

Website: www.actascientific.com/

Submit Article: www.actascientific.com/submission.php Email us: editor@actascientific.com

Contact us: +919182824667 